\title{
DNA Damage Response
}

\author{
Giuseppina Giglia-Mari ${ }^{1,2,3}$, Angelika Zotter ${ }^{1,4}$, and Wim Vermeulen ${ }^{1}$ \\ ${ }^{1}$ Department of Genetics, Erasmus University Medical Center, Dr Molewaterplein 50, 3015 GE Rotterdam, \\ The Netherlands \\ ${ }^{2}$ Department of Cancer Biology, Institute of Pharmacology and Structural Biology, CNRS, \\ 205 route de Narbonne, 31077 Toulouse, France \\ ${ }^{3}$ Université de Toulouse Paul Sabatier, 31000, Toulouse, France \\ ${ }^{4}$ Core Research Laboratory, Istituto Toscano Tumori, Villa delle Rose, Via Cosimo il Vecchio 2, \\ 50139 Firenze, Italy \\ Correspondence: w.vermeulen@erasmusmc.nl
}

Structural changes to DNA severely affect its functions, such as replication and transcription, and play a major role in age-related diseases and cancer. A complicated and entangled network of DNA damage response (DDR) mechanisms, including multiple DNA repair pathways, damage tolerance processes, and cell-cycle checkpoints safeguard genomic integrity. Like transcription and replication, DDR is a chromatin-associated process that is generally tightly controlled in time and space. As DNA damage can occur at any time on any genomic location, a specialized spatio-temporal orchestration of this defense apparatus is required.

Selective advantage by random mutations in the genetic material has driven evolution of terrestrial life. Despite this obvious advantage for biological diversity, genome instability has in most cases adverse effects on organismal life. Preservation of genomic integrity is a prerequisite for proper cell function and faithful transmission of the genome to progeny. However, environmental factors and the chemical properties of DNA do not guarantee lifelong stability and proper functioning of the genome.

Genomic insults arise from side effects of DNA metabolizing processes, such as replication errors, uncontrolled recombination, off-target mutation induction by somatic hypermutation during antigen production, and inaccurate VDJ recombination (Liu and Schatz 2009; Mahaney et al. 2009). The biggest genomic burden is, however, induced by processes that directly damage DNA. DNA lesions are derived from three main sources (Lindahl 1993; Friedberg et al. 2006): environmental agents such as ultraviolet light, ionizing radiation, and numerous genotoxic chemicals; reactive oxygen species (ROS) generated by respiration and lipid peroxidation; and spontaneous hydrolysis of nucleotide residues, inducing abasic sites and deamination of C, A, G, or 5methyl-C. It is estimated that each cell is confronted with approximately $10^{4}-10^{5}$ lesions per day, indicating that clearance of genomic injuries constitutes

Editors: Tom Misteli and David L. Spector

Additional Perspectives on The Nucleus available at www.cshperspectives.org

Copyright (C) 2011 Cold Spring Harbor Laboratory Press; all rights reserved; doi: 10.1101/cshperspect.a000745

Cite this article as Cold Spring Harb Perspect Biol 2011;3:a000745 


\section{G. Giglia-Mari, A. Zotter, and W. Vermeulen}

a demanding task to maintain proper genome function.

Essential genome processes, such as transcription and replication, are severely affected by DNA lesions. Replication over damaged DNA induces mutations, which may initiate and propagate carcinogenesis. Acute effects arise when lesions block transcription causing cellular senescence or apoptosis, resulting in damageinduced accelerated aging (Mitchell et al. 2003; Akbari and Krokan 2008; Sinclair and Oberdoerffer 2009).

\section{THE DNA DAMAGE RESPONSE}

To deal with the fundamental problem of genomic erosion, a sophisticated network of DNA damage-response (DDR) systems has evolved. These include a set of DNA repair mechanisms, damage tolerance processes, and cell-cycle checkpoint pathways. The biological significance of a functional DDR for human health is clearly illustrated by the severe consequences of inherited defects in DDR factors resulting in various diseases, including immune deficiency, neurological degeneration, premature aging, and severe cancer susceptibility (Hoeijmakers 2001; Hoeijmakers 2009).

\section{DNA Repair Mechanisms}

The heart of the cellular defense against DNA injuries is formed by a variety of DNA repair mechanisms (Hoeijmakers 2001; Hoeijmakers 2009), each with their own damage specificity (Table 1). Together, they are able to remove the vast majority of injuries from the genome. The simplest solution that emerged in evolution is the direct reversal of lesions by specialized activities, such as photolyases that selectively

Table 1. Induction of DNA lesions and corresponding repair pathway.

\begin{tabular}{|c|c|c|}
\hline Lesion & Cause & Repair process(es) \\
\hline $\mathrm{CPD}, 6-4 \mathrm{PP}^{(1)}$ & Sunlight & NER \\
\hline Bulky adducts ${ }^{(2)}$ & Food, cigarette smoke & NER \\
\hline Intrastrand crosslinks & Chemotherapy (e.g., Cis-Pt) & NER \\
\hline 8-oxo-dG ${ }^{(3)}$ & $\operatorname{ROS}^{(4)}$, respiration & BER \\
\hline Thymineglycol $^{(3)}$ & $\operatorname{ROS}^{(4)}$, respiration & BER \\
\hline $\mathrm{N}^{7}$-Alkyl-dG, N ${ }^{3}$-Alkyl-dA & Food, pollutants & BER \\
\hline $\mathrm{O}^{6}$-Alkyl-dG & Food, pollutants & $\mathrm{DR}^{(5)}, \mathrm{BER} ?$ \\
\hline 5-methyl-dC & $\mathrm{DNMT}^{(6)}$ & BER/AID-BER/NER? ${ }^{(7)}$ \\
\hline Uracil, (Hypo)Xanthine & Spontaneous deamination & BER \\
\hline Abasic site & Spontaneous hydrolysis & BER \\
\hline Single-strand breaks & Ionizing radiation, ROS & Ligation, BER \\
\hline Double-strand breaks & Ionizing radiation, ROS, VDJ-rec & HR, NHEJ \\
\hline Tyrosyl-3'DNA ${ }^{(8)}$ & Topo-I inhibition, ROS & SSBR \\
\hline Mismatches & Replication errors & MMR \\
\hline Small insertion/deletions & Replication slippage & MMR \\
\hline Interstrand crosslinks & Chemotherapy & ICLR/ HR? \\
\hline
\end{tabular}

1. CPD: cyclobutane pyrimidine dimer; 6-4 PP: 6-4 pyrimidine-pyrimidone photo-product.

2. A large group of chemicals conjugated to bases that cause DNA helix destabilization such as: Benzo $[\alpha]$ pyrene (a polycylic aromatic hydrocarbon); Aflatoxins (present in fungal food contaminations); and Nitrosamines (tobacco smoke).

3. A large group of different oxidation products affecting either the base or the phosphate-sugar backbone of which 8 -oxo-dG is the most abundant.

4. ROS: reactive oxygen species, produced as side-product of respiration/metabolism and ionizing radiation.

5. DR: direct reversal, involving the suicide enzyme MGMT.

6. DNMT: DNA methyltransferase, functions in epigenetic gene-expression control (e.g., at CpG islands).

7. The mechanism of 5-Me-C repair/conversion is a matter of debate. Recently, a GADD45a-dependent NER reaction was suggested (Barreto et al. 2007).

8. Proteolytic degradation of conjugated Topo-I to $3^{\prime} \mathrm{DNA}$ termini creates tyrosyl-3'DNA bonds, resolved by TDP1 (El-Khamisy et al. 2009). 
reverse UV-induced DNA damage (Weber 2005) and the suicide enzyme $\mathrm{O}^{6}$-methylguanine transferase (MGMT) that transfers the methyl group from DNA by covalently coupling it to an internal cysteine residue of MGMT, thereby destroying the enzymatic activity (Friedberg et al. 2006). Photolyases are not conserved into the mammalian branch and mammals have to rely on a more complex mechanism to remove UV injuries: nucleotide excision repair (NER) (see below).

\section{Base Excision Repair (BER)}

Bases with small chemical alterations that do not strongly disturb the DNA double-helix structure are substrates for Base Excision Repair (BER) (Almeida and Sobol 2007; Hegde et al. 2008) (Table 1). These damages, or group of lesions, are targeted by lesion-specific DNA glycosylases that both recognize and remove the damaged base from the sugar-phosphate backbone. The resulting abasic (AP) site is incised by AP-endonucleases and the single nucleotide gap is filled-in by the BER-specific DNA polymerase $\beta$ and finally sealed by the XRCC1/Ligase III complex. Single strand breaks (SSBs) are repaired by a specialized BER mechanism, designated single-strand break repair (SSBR). The abundant nuclear protein Poly-ADP-RibosePolymerase (PARP) is rapidly activated by SSBs and causes auto-poly-ADP-ribosylation, which recruits the XRCC1/ligase III complex as well as end-processing enzymes such as aprataxin (Gueven et al. 2004) and TDP1 (tyrosyl-DNAphosphodiesterase) to create ligatable DNA ends (Caldecott 2007; El-Khamisy et al. 2009).

\section{Nucleotide Excision Repair (NER)}

NER removes a broad spectrum of single-strand lesions that cause local helix-destabilization (Table 1). NER is a complex multi-step process, involving the concerted action of at least 25 different polypeptides (Hoeijmakers 1993; Gillet and Scharer 2006) (Fig. 1). Two different modes of damage detection are operational in NER: transcription-coupled NER (TC-NER), which efficiently removes transcription-stalling lesions and allows quick resumption of transcription (Bohr et al. 1986; Hanawalt 1994), and global genome NER (GG-NER), which localizes lesions anywhere in the genome. In TC-NER, damage sensing is performed by the stalled RNA polymerase, and the Cockayne syndrome factors A and B (CSA and CSB) play essential roles in TC-NER complex assembly (Fousteri et al. 2006; Fousteri and Mullenders 2008). Lesion discrimination in GG-NER is executed by the concerted action of two complexes: XPC/hHR23B (Masutani et al. 1994) and UVDDB (DDB1 and DDB2/XPE) (Chu and Chang 1988; Keeney et al. 1994; Sugasawa et al. 2009). The subsequent steps of TC-NER and GG-NER converge into a common mechanism in which first the NER/basal transcription factor TFIIH (Egly 2001) is recruited (Yokoi et al. 2000; Volker et al. 2001). The bi-directional helicase of TFIIH opens the damaged DNA segment over a stretch of approximately 30 nucleotides (Sugasawa et al. 2009). The unwound DNA is stabilized by XPA and RPA (Replication Protein A) that also orient (de Laat et al. 1998) the two structure-specific endonucleases XPG (O'Donovan et al. 1994) and the ERCC1-XPF complex (Sijbers et al. 1996), which respectively incise the damaged strand $3^{\prime}$ and $5^{\prime}$ with respect to the lesion. The resulting 25-30 nucleotide single strand gap is filled in by normal DNA replication proteins, including replication factor C (RFC), PCNA, $\mathrm{RPA}$, and the DNA polymerases $\delta$, $\varepsilon$, or $\kappa$ (Ogi et al. 2010). Finally, the gap is sealed by DNA ligases I or III, dependent on the proliferation status of the cell (Moser et al. 2007) (Fig. 1).

\section{DNA Double-Strand Break Repair (DSBR)}

Lesions that are substrates for NER and BER are located in one of the strands of DNA and are removed in a "cut-and-patch"-mechanism. In both cases, the undamaged complementary strand serves as a faithful template for the repair of the damaged strand. Some damaging agents, however, affect both strands, such as ionizing radiation that induces DNA double-strand breaks (DSBs) and agents that produce inter-strand cross-links (ISCLs) (Table 1). These lesions are extremely cytotoxic because they are more 
G. Giglia-Mari, A. Zotter, and W. Vermeulen

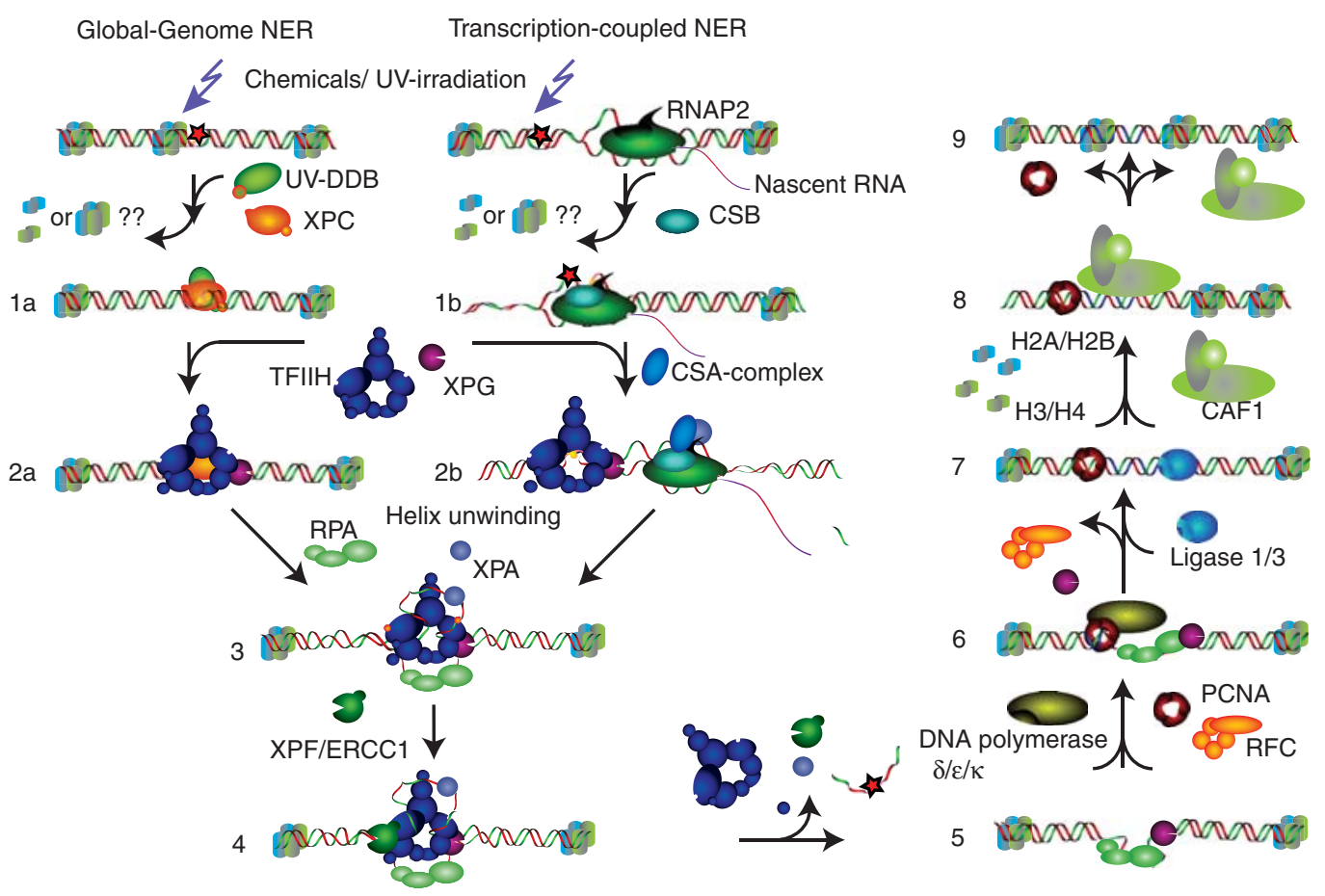

Figure 1. Molecular mechanism of nucleotide excision repair (NER). Bulky DNA lesions (e.g., UV-induced photo-products and chemical conjugates to nucleotides) that destabilize the DNA double-helix are targeted by NER. Damage recognition is performed by transcription-coupled NER (TC-NER) and Global Genome NER (GG-NER). It is suggested that prior to damage recognition, chromatin has to be modified. Lesions in the transcribed strand of active genes are detected by the elongating RNA polymerase II (RNAP2) and stabilize the interaction with CSB (step 1b). Within GG-NER, lesions are recognized by the UV-DDB and the XPC complexes (step 1a). These intermediates load transcription factor TFIIH together with the endonuclease XPG (steps $2 \mathrm{a}$ and $2 \mathrm{~b}$ ). In TC-NER, CSA is also recruited to modify and reposition lesion-stalled RNAP2 (step 2b). After the two modes of lesion detection, the two processes merge into a common pathway of NER factor assembly by recruiting XPA and replication protein A (RPA) (step 3). This NER-intermediate loads and properly orients the structure-specific endonuclease ERCC1/XPF complex (step 4). After dual incision by XPG ( $3^{\prime}$ from the lesion) and ERCC1/XPF ( $5^{\prime}$ from the lesion), a single-strand of 25-29 nucleotides is created (step 5). XPG is likely involved in recruiting the sliding clamp PCNA, which is loaded by RFC and forms the platform for the gap-filling DNA polymerases $\delta$, $\varepsilon$, or $\kappa$ (step 6). Each of these polymerases has been found to participate in NERdependent gap-filling. PCNA or RFC are likely also involved in recruiting the ligases (i.e., Ligase I and Ligase III/ XRCC1, depending on the proliferation capacity of the cell) to seal the nick (step 7). PCNA also plays a role in attracting the histone-chaperone CAF1 (step 8) to restore the chromatin structure after repair (stage 9).

difficult to repair as the cell cannot rely on simply copying the information from the undamaged strand. Two distinct pathways, homologous recombination (HR) and nonhomologous end-joining (NHEJ), repair DSBs (Cahill et al. 2006; Wyman and Kanaar 2006; Helleday et al. 2007). The division of tasks between these repair mechanisms is mainly determined by the phase of the cell cycle. As
HR requires a homologous sister chromatid, it acts exclusively in S- and G2-phase. In contrast, post-mitotic cells and cycling cells in G1 phase have to seal DSBs by NHEJ.

Within NHEJ, breaks are quickly recognized by the Ku70/Ku80 hetero-dimer that activates the PI3-kinase DNA-PK and sets the scene for subsequent recruitment of the Artemis nuclease and the MRE11/Rad50/NBS1 (MRN) protein 
complex. These proteins are involved in DNA end-processing, preceding ligation performed by the XRCC4/LigaseIV complex (Weterings and van Gent 2004; Burma et al. 2006; van Gent and van der Burg 2007). During DNA end-processing, loss or changes of a few nucleotides may occur. For this reason, NHEJ, although it very rapidly seals DSBs, is an errorprone repair process.

However, when cells do have a homologous template, as in the S- and G2-phase of the cycle, DSBs can be repaired by HR. Homologous recombination is initiated by binding of the MRN complex to a DSB and functions to hold the broken pieces together (de Jager et al. 2001) and provides the structural bases for the CtIP nuclease. The MRN-CtIP complex catalyzes end resection at the break in concert with exonuclease I (EXO1) (Limbo et al. 2007; Sartori et al. 2007; Takeda et al. 2007). Subsequently, RPA binds to the newly created singlestrand region and through a complicated handoff mechanism, the RPA-filament is exchanged into a RAD51 nucleo-protein filament. This RAD51-filament is crucial for strand invasion into the homologous sister, creating a temporarily triplex-DNA structure in which strand exchange occurs (Wyman et al. 2004). The molecular details of these complex transactions are as yet enigmatic, although genetic studies have revealed a whole list of proteins that play an important role in these transactions (Lisby and Rothstein 2009). The biggest challenge within HR-driven DSBR is, however, the question on how homologous regions are identified within the complex nuclear environment.

\section{DNA Damage Tolerance}

Persisting lesions not removed by any of the repair mechanism will interfere with DNA replication. Lesion-stalled replication forks can lead to highly cytotoxic DSBs and require a prompt response. At least two DNA damage tolerance mechanisms have evolved: translesion synthesis (TLS) and recombination-dependent daughter-strand gap repair (DSGR) (Scully et al. 2000; Li et al. 2002). These processes do not actually remove lesions, but serve as a temporary solution to overcome stalled DNA replication machines. Upon lesion-induced replication blockage, the regular high-fidelity DNA polymerases ( $\operatorname{pol} \delta / \varepsilon$ or $\alpha$ ) are temporarily exchanged with translesion polymerase ( pol $\zeta-\kappa)$ (Friedberg et al. 2005; Lehmann 2006) to synthesize across the lesion. Although TLS can circumvent lesion-induced replication stalling, the reduced fidelity of the alternative polymerases causes generally enhanced mutagenesis.

\section{Damage Signaling}

To create an extended time window to allow completion of lesion removal prior to replication or cell division, damage sensing is linked to an intricate signal transduction cascade that induces cell cycle arrest (Bartek et al. 2007; Callegari and Kelly 2007). Depending on the nature of the DNA injury and the phase of the cell cycle in which the lesion is encountered, the cell cycle can be arrested at the G1/S transition, within the S-phase, or at the G2/M transition (Zhou and Elledge 2000). Alternatively, when too many injuries are encountered, apoptosis is triggered in order to protect the organism from potentially harmful cells (Bernstein et al. 2002). The phosphatidylinositol 3-kinase (PI3) ATM (Ataxia Telangiectasia mutated) is directly recruited and activated by the DSB-recognizing protein complex MRN. This initiating kinase transduces phosphorylation to a high number of adapter/transducer proteins, carrying the ATM-consensus sequence (Matsuoka et al. 2007). Finally, downstream effector kinases, such as the checkpoint kinase Chk2, are activated (Falck et al. 2002). Bulky lesions cause replication collapse that induces single-strand DNA by the retraction of the replication fork. RPA binds to ssDNA and recruits ATR (ATMrelated) via its association with ATRIP (ATR interacting protein) and activates the checkpoint protein Chk1 (Tibbetts et al. 2000; Chen and Sanchez 2004). RPA covered ssDNA also triggers the Rad17-dependent loading of the RAD9-HUS1-RAD1 (9-1-1 complex), which is an important transducer of checkpoint activation upon DNA damage (Smits et al. 2010). A third PI3 kinase, DNA-PK (DNA-dependent 
protein kinase, composed of its catalytic subunit DNA-PKcs and a regulatory Ku70/80 heterodimer), is also activated by IR-induced DSBs. DNA-PKcs is essential for NHEJ in higher eukaryotes (Burma et al. 2006) and additionally functions in telomere maintenance and induction of apoptosis (Burma and Chen 2004). In total, a complicated set of different emergency strategies are called into action when genomic insults are encountered. Although many of the individual players are identified and the downstream signaling cascades have been dissected, their respective interactions and communication is far from resolved.

\section{Intertwined DNA-transacting Processes}

The different repair processes are generally considered separate entities. However, in recent years, it has become clear that most of these DDR processes are part of an intricate network with significant overlap, often sharing specific essential components.

Several DDR factors appeared to act in diverse DNA maintenance systems. One typical example is the hetero-dimeric ERCC1/XPF complex. This structure-specific endonuclease was originally identified as the nuclease that incises $5^{\prime}$ of the DNA lesions within NER (Westerveld et al. 1984; Sijbers et al. 1996). Further analysis revealed additional functions for this complex in HR (Adair et al. 2000; Niedernhofer et al. 2001), interstrand cross-link repair (De Silva et al. 2000; Niedernhofer et al. 2004), and telomere maintenance (Zhu et al. 2003).

Besides overlap between distinct repair processes, DDR is also linked to other essential DNA transacting mechanisms, such as transcription and replication. A prime example of such a link is the tight connection between NER and transcription, illustrated by the existence of a specialized transcription-coupled NER pathway (TC-NER) (Bohr et al. 1985; Fousteri and Mullenders 2008). The chromatin remodeling protein Cockayne Syndrome B (CSB) (Citterio et al. 2000) is essential for TC-NER and is implicated in transcription elongation (van den Boom et al. 2004). Moreover, the basal RNA polymerase II transcription factor TFIIH is also a pivotal factor in NER (Fig. 1) (Schaeffer et al. 1993; Drapkin et al. 1994; Egly 2001; Hoogstraten et al. 2002). Finally, the essential replication factor A (RPA) is implicated in basically all DDR mechanisms, including NER, HR, and damage signaling.

Different strategies are used to control the multi-functionality of these factors: (1) distinct spatial organization, (2) incorporation into diverse functional complexes, and/or (3) dynamic sharing of these components. Regulation of pleiotropic functionality of proteins is commonly achieved by distinct posttranslational modifications (PTMs). Within DDR, different PTMs were identified, ranging from phosphorylation, acetylation, methylation, neddylation, mono- and poly-ubiquitylation, and sumoylation to poly-ADP-ribosylation (Harper and Elledge 2007; Huen and Chen 2008). One of the most common PTMs involved in DDR is differential phosphorylation, mainly driven by the ATM, ATR, and DNA-PKcs kinases (Matsuoka et al. 2007). Recent research indicates also that differential ubiquitination plays an important role in DDR regulation (Bergink et al. 2007; Harper and Elledge 2007; Reed and Gillette 2007; Huen and Chen 2008; Alpi and Patel 2009; Panier and Durocher 2009).

\section{STRUCTURAL AND FUNCTIONAL ORGANIZATION OF DDR}

\section{Chromatin and DDR}

The nucleus is highly structured and functionally compartmentalized in part due to areas of various degrees of chromatin compaction, creating possible obstacles for DDR factor accessibility. Decompaction and subsequent restoration of the starting chromatin structure in conjunction with DDR thus creates another level of complexity in genome maintenance regulation. Chromatin-associated processes such as transcription, replication, and DNA repair are regulated by a complex set of structural changes in chromatin (Groth et al. 2007; Li et al. 2007). Control of chromatin functions and its compaction occurs by at least four known processes: (1) active ATP-consuming 
remodeling machines of the SWI/SNF-superfamily of DNA-dependent ATPases (NevesCosta and Varga-Weisz 2006; Saha et al. 2006) that slide or physically evict core histones or entire nucleosomes from active sites; (2) incorporation of diverse histone variants by histone chaperones (Loyola and Almouzni 2007; Altaf et al. 2009); (3) differential binding of abundant non-core histone proteins, such as the linker histone $\mathrm{H} 1$, the family of high mobility group proteins (HMG), or different isoforms of the hetero-chromatin protein 1 (HP1); and (4) covalent modifications or PTMs of the core histones, such as acetylation, methylation, phosphorylation, and ubiquitylation ( $\mathrm{He}$ and Lehming 2003). Accordingly, recently a large number of chromatin modifications and remodeling events were shown to be linked to DDR (Groth et al. 2007; Dinant et al. 2008; Misteli and Soutoglou 2009; Nag and Smerdon 2009; van Attikum and Gasser 2009).

\section{Access, Repair, and Restore}

Despite increasing knowledge of the role of chromatin in DDR, a general mode of action or detailed mechanistic insight is lacking. Already in 1991 a hypothetical three step model for DNA repair in chromatin was postulated (Smerdon 1991), the so-called "ARR-model," for Access, Repair, and Restore, based on analogy to transcription regulation in chromatin. In this model, it was postulated that chromatin remodeling would be required to provide "access" of damage-recognition factors to initiate "DNA repair" and, when the job is finished, "restoration" of the chromatin structure. Since then, clear indications have been found that the $\mathrm{H} 3 / \mathrm{H} 4$ chaperone CAF1, likely in conjunction with Asf1 (anti-silencing function 1), is implicated in restoring chromatin after NER (Green and Almouzni 2002; Mello et al. 2002; Polo et al. 2006). Additional studies implicated Asf1 and FACT (facilitating transcription factor) (Chen et al. 2008; Heo et al. 2008) in histone exchange near DSBs. However, less direct evidence for chromatin remodeling factors for the first step (access) was found. Although several chromatin remodelers, such as INO80
(Downs et al. 2000; van Attikum et al. 2004), facilitate DDR factor recruitment by moving histones away from the break, they appear to act after the initial damage recognition. In addition, chromatin modifications in yeast occur after UV-irradiation by Gcn5-induced H3 acetylation and are dependent on the Swi/Snf DNA translocase Rad16/Rad7/Abf1. Despite the more open chromatin structure by hyperacetylation, it is not directly clear whether this modification facilitates the recruitment of the Rad4 (yeast ortholog of XPC) DNA damage recognition protein (Waters et al. 2009).

\section{Phosphorylation of the Histone $H 2 A$ Variant $\mathrm{H} 2 \mathrm{AX}$}

The most prominent DDR-associated covalent histone modification is the phosphorylation of the histone $\mathrm{H} 2 \mathrm{~A}$-variant $\mathrm{H} 2 \mathrm{AX}$ in response to DNA damage by the checkpoint kinases ATM, ATR, and DNA-PKcs (Rogakou et al. 1998; O'Driscoll et al. 2003; Falck et al. 2005). $\mathrm{H} 2 \mathrm{AX}$ is incorporated into approximately $5 \%-25 \%$ of histone octamers, although its phosphorylation $(\gamma \mathrm{H} 2 \mathrm{AX})$ is constrained to microscopically discernable structures, the ionizing irradiation-induced foci (IRIF) (Fig. 2). Phosphorylation of $\mathrm{H} 2 \mathrm{AX}$ is a relatively early event after damage, immediately following MRN binding and ATM activation. These $\gamma \mathrm{H} 2 \mathrm{AX}$ foci co-localize with most of the DSB-associated DDR factors (see below) and are thought to serve as docking sites for recruiting and retaining DNA repair and signaling factors to DSBs. $\gamma$-H2AX spreads over several megabases around DSBs and appears condensed into IRIFs (Rogakou et al. 1999), suggesting a dominant structural role in DSB-DDR. Surprisingly, however, although mice lacking $\mathrm{H} 2 \mathrm{AX}$ are radiation-sensitive and exhibit several features associated with defective DDR, they are only partially defective in DSB repair and are not fully compromised in checkpoint activation (Celeste et al. 2002). This notion argues, contrary to expectation, that this impressive structural organization into large molecular assemblies only makes the DDR process more efficient but is not essential for DDR. 


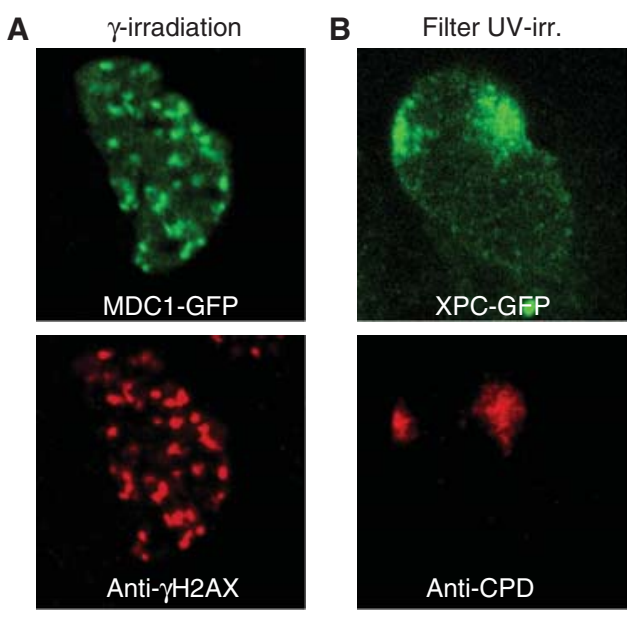

Figure 2. Localization of DSBR and NER factors. Typical examples of subnuclear distributions of MDC1, an important factor involved in an early step of DNA double-strand break repair via homologous recombination $(A)$ and XPC, one of the damage-recognizing proteins in NER $(B)$. ( $A$ ) GFP signal (upper panel) derived from MDC1-GFP stably expressed in U2OS cells, 2 hours after $\gamma$-irradiation and fixed with paraformaldehyde, showing the accumulation of MDC1 in typical ionizing-radiation induced foci (IRIF), counter stained with anti- $\gamma-\mathrm{H} 2 \mathrm{AX}$ antibodies (lower panel). (B) NER factors do not accumulate in nuclear foci after DNA damage induction. To allow live cell analysis of NER factor kinetics, local UVdamage infliction through a micro-porous filter is performed (see Fig. 3B,C). XPC-GFP expressed in human fibroblasts (upper panel) accumulates at local UV-damaged sub-nuclear areas as recognized by anti-CPD (the major UV-induced DNA lesion) antibodies (lower panel).

UV-light also induces $\gamma$-H2AX, although in this case the modification is homogenously distributed throughout the nucleus, with the exception of cells in S-phase (O'Driscoll et al. 2003; Hanasoge and Ljungman 2007; Stiff et al. 2008). H2AX phosphorylation upon UV in non-S-phase cells depends on ATR and active processing of the lesion by the NER machinery (O’Driscoll et al. 2003; Marti et al. 2006), suggesting that NER-intermediates trigger this response. The notion that $\gamma-\mathrm{H} 2 \mathrm{AX}$ formation occurs in response to NER and that NER is proficient in H2AX-deficient cells, suggests that this modification mainly plays a role in checkpoint activation during UV lesion repair.

\section{DDR in Higher Order Chromatin Structure}

Within mammalian cells, chromatin comes in different flavors, classified into compacted and often transcription-silent heterochromatin and the more open transcriptionally active euchromatin. Chromatin compaction is, however, dynamic and varies within different nuclear areas, throughout the different phases of the cell cycle and between different somatic cell types. Obviously, higher order packaging beyond the basic nucleosomal level will raise further accessibility problems. The versatile NER pathway removes lesions throughout the genome, although repair of photo-lesions in nucleosomal templates is repaired slower in vitro compared to naked DNA (Nag and Smerdon 2009). Evidence for an inhibitory effect of higher order chromatin structure on NER in vivo is restricted to yeast studies. Yeast mutants for the histone acetyltransferase Gcn5, which affect chromatin packaging of specific loci, exhibit significant reduced UV-lesion repair on these silenced loci (Waters et al. 2009).

Evidence for reduced repair kinetics of DSBs in compact heterochromatin was recently provided (Goodarzi et al. 2008). Repair in these areas requires the release of the heterochromatin-associated and transcriptional co-repressor protein KAP1 (KAP-associated protein 1) from these compact regions. This release appeared to depend on phosphorylation by ATM, providing evidence for a direct role of this important DSB PI3-kinase in chromatin decompaction to support DDR. ATM-dependent repair in heterochromatin can also be alleviated by depletion of the heterochromatic factor HDACl/2 and simultaneous depletion of the three isoforms $(\alpha$, $\beta$, and $\gamma$ ) of HP1 (heterochromatin protein 1). The implication of this protein in DDR has recently led to controversy in the DDR literature (Ball and Yokomori 2009), as one group describes a DNA damage-induced release of phosphorylated HP1 from H3K9me (Histon H3, lysine 9 methylation) (Ayoub et al. 2008), while Luijsterburg and co-workers report recruitment of HP1 to damaged sites (Luijsterburg et al. 2009). Ayoub showed an initial release of phosphorylated HP1 followed by a subsequent 
spreading to neighboring chromatin. This discrepancy is difficult to explain, besides possible difference in DNA damage induction and slight differences in kinetic measurements. A possible explanation for the apparent initial disappearance prior to the observed accumulation at damaged sites might be the sudden highly localized damage induction. The extreme high local concentration of light might in addition to DNA damage also induce chromatin-protein damage. The next wave of HP1 accumulation reflects then the more physiological response to DNA damage induction. Despite the conflicting data and interpretations, it is clear that compaction of chromatin and HP1 play an as yet not entirely understood role in DDR, as disruption of HP1 orthologs in C. elegans induces a diverse spectrum of DNA damage sensitivities (Ball and Yokomori 2009; Luijsterburg et al. 2009).

\section{Tools to Analyze DDR in Living Cells}

The dynamic interactions with chromatin and the multiple engagements of DDR factors indicate that analysis of each of the separate processes in vitro is not sufficient to fully uncover mechanistic details, and demands cellular biological approaches. The possibility to genetically tag proteins with the autofluorescent protein GFP has revolutionized cell biology (Tsien and Miyawaki 1998). The simultaneous technological advances in microscopy and development of quantitative fluorescent measurements and sophisticated photo-bleaching procedures (White and Stelzer 1999; Houtsmuller and Vermeulen 2001; LippincottSchwartz et al. 2001) have provided spectacular new insights into the regulation and dynamic organization of chromatin-associated processes (Houtsmuller et al. 1999; Phair and Misteli 2000). In particular, the development of several systems to locally introduce DNA damage or immobilize DDR factors in cultured living cells has been beneficial (Figs. 2 and 3): (1) irradiation through a filter or mask that partly shield the cells (Nelms et al. 1998; Katsumi et al. 2001; Mone et al. 2001); (2) micro-beam laser irradiation, with or without photo-sensitizers, at sub-nuclear areas (Cremer et al. 1980; Tashiro et al. 2000; Lukas et al. 2003; Meldrum et al. 2003; Lan et al. 2004; Dinant et al. 2007); (3) guided $\alpha$-particle and heavy iron radiation (Jakob et al. 2003; Aten et al. 2004; Hauptner et al. 2004); (4) integration of rare-cutting endonucleases (Lisby et al. 2004; Rodrigue et al. 2006; Soutoglou et al. 2007); and (5) DDR protein tethering to specific integrated amplified sequences (Soutoglou and Misteli 2008).

\section{Organization of DNA Double-Strand Break Response}

In situ studies revealed that next to $\gamma$-H2AX, a high number of DDR proteins relocalize into IRIF foci upon genomic stress (Bekker-Jensen et al. 2006). This is particularly pronounced for proteins implicated in the repair and signaling of DSBs by homologous recombination (HR) (Fig. 2). A systematic analysis of the spatial distribution of DSB-DDR factors using a method to locally introduce DSBs in cultured living cells (Lukas et al. 2003) resulted in a localization classification of DDR factors (Bekker-Jensen et al. 2006). In this procedure, cells were cultured in the presence of photo-sensitizing nucleotideanalogs (Iodo-deoxyuridine) prior to microbeam laser irradiation with $337 \mathrm{~nm}$ that induces DSB in a user-defined sub-nuclear area (Lukas et al. 2003). Several subclasses of repair proteins were found based on their recruitment properties: (1) The major checkpoint mediators, such as Mdc1 (mediator of DNA damage checkpoint protein 1), 53BP ( $\mathrm{p} 53$ binding protein), BRCA1 (breast cancer protein 1), ATM, and the MRN complex, co-localize in IRIF with $\gamma$-H2AXdecorated chromatin, termed "DSB-flanking chromatin". Assembly of these proteins at the DSB-flanking chromatin appeared to occur throughout the cell cycle. It has been estimated that these foci contain several hundred copies of each of the participating DDR factors. (2) Another group of DSB-activated proteins assembles in much smaller ssDNA micro-compartments that are most likely formed by $5^{\prime}$ resections at DSB, an important $\mathrm{HR}$ intermediate. These "microfoci" are only formed in S- and G2-phase cells and typically accumulate next to $\mathrm{RPA}$, factors directly involved in HR repair, like 
G. Giglia-Mari, A. Zotter, and W. Vermeulen

A
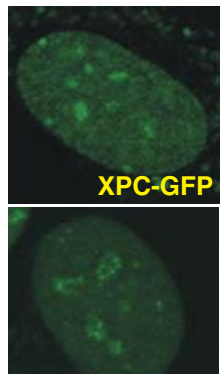

TFIIH-GFP

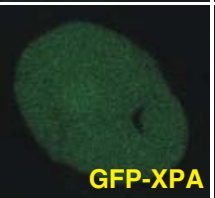

D

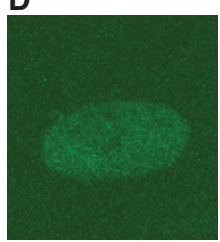

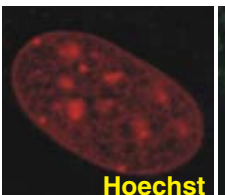
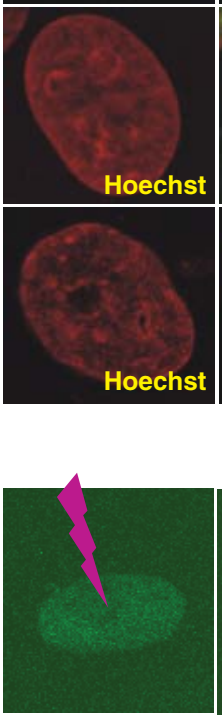

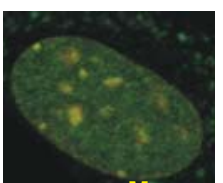

Merge
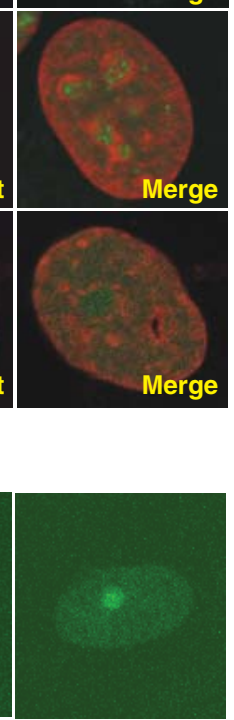

B

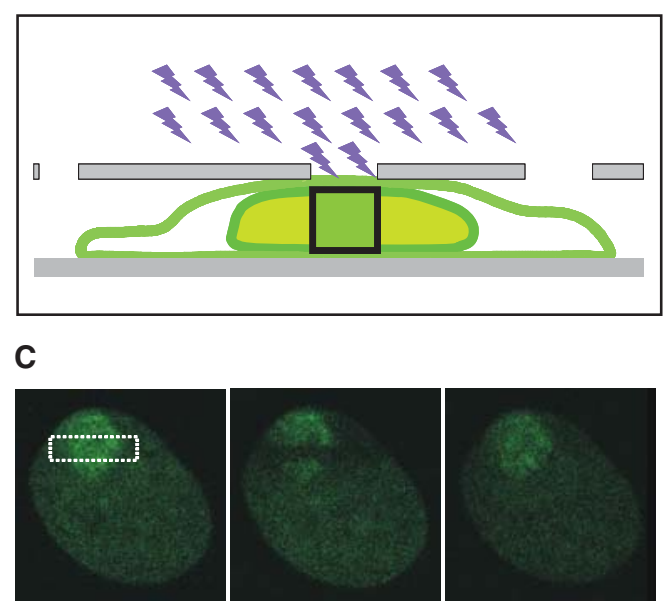

E

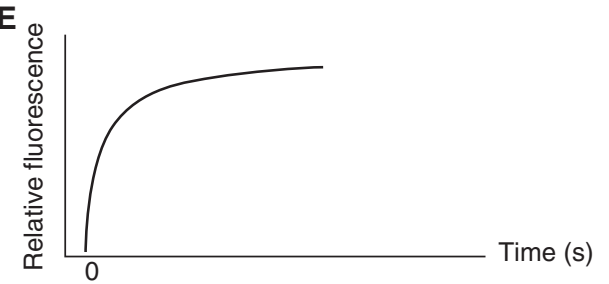

Figure 3. Live cell analysis of NER. (A) Distribution of three different NER factors tagged with GFP in living cells; DNA is stained by the DNA stain Hoechst. The damage recognition factor XPC is concentrated in nuclear areas (top panel) that also contain high DNA concentrations when the XPC-GFP (Hoogstraten et al. 2008) is expressed in mouse-embryonal fibroblasts that exhibit the species-specific dense DNA-containing areas. This inhomogeneous distribution contrasts to other NER factors such as XPA (Rademakers et al. 2003), which are homogenously distributed (lower panel) and the repair/transcription factor TFIIH that is enriched in nuclei (Hoogstraten et al. 2002). (B) Schematic cartoon of the procedure to locally inflict UV-damage in living cultured cells by irradiation through a microporous filter (Volker et al. 2001). (C) Local accumulation of XPB-GFP (TFIIH subunit) in UV-damaged areas used to determine the dwell time of this NER factor in the damaged area by fluorescence recovery after photo bleaching (FRAP). (D) Human fibroblasts expressing XPC-GFP locally damaged at the indicated position (purple flash, middle panel) by UV-C laser (Dinant et al. 2007). The right panel shows a clear accumulation of this protein as soon as 30 seconds after irradiation. (E) Schematic representation of the quantification of NER factor time-dependent accumulation at local UV-damage in living cells to determine the assembly kinetics of these factors within the chromatin-bound NER complex.

Rad51, Rad52, BRCA1, and FANCD2 (Fanconi anemia complementation group D2). They also contain the ssDNA-activated checkpoint kinase ATR and the 9-1-1 complex (Warmerdam et al. 2009). Also MRN and BRCA1 were found in these microfoci independent of $\gamma-\mathrm{H} 2 \mathrm{AX}$ or Mdc1, while their recruitment to DSB-flanking chromatin is dependent on these proteins. (3) Several DSB repair factors, particularly those involved in NHEJ, such as DNA-PKcs and $\mathrm{Ku} 70 / 80$, could not be found to re-localize into microscopically discernible foci. It is likely that this process proceeds much faster than HR and that NHEJ factors do not need to be loaded in such large molecular assemblies to execute their function. However, using procedures that introduce high local concentrations of breaks in living cells, with the aid of multi-photon micro-beam laser irradiation, microscopically discernible accumulations of NHEJ could be found (Mari et al. 2006; Uematsu et al. 2007). These accumulations likely reflect high local 
concentrations of breaks and repair factors rather than a specific chromatin structure. (4) Other factors implicated in DSB processing do not exhibit discernible accumulation at sites of damage, since these proteins are omnipresent on chromatin and simply get post-translationally modified at or near breaks. One of them is Smcl (Structural Maintenance of Chromosomes 1), a structural component of the cohesin complex required for sister chromatid cohesion during S-phase and also implicated in DSB repair. Smcl is phosphorylated on Serine 957 (a canonical ATM target site) by ATM and ATR after exposure to a broad array of stimuli including IR, HU, and UV-light (Kim et al. 2002). (5) While many of the DDR factors are recruited or retained at the site of damage, proteins like the effector kinases Chk1 and Chk2 are released from chromatin in response to DNA damage. Activated checkpoint proteins distribute through to nucleus to activate soluble pan-nuclear targets such as p53 and Cdc25A (Kastan and Bartek 2004). Also, these effectors, crucial for efficient DNA damageinduced gene expression ( p53) and cell-cycle arrest (Cdc25A, p53), do not accumulate at DNA damage sites.

\section{Dynamics and Function of IRIF}

One obvious question is: What is the function of IRIFs? Although they are certainly associated with DSBs, this seemingly easy question is, however, difficult to answer, and different models can be envisaged; for example, foci may (1) represent sites of active DSB repair or (2) sites refractory or difficult to repair. Determining the dynamics of these structures might shed some light. Dwell time measurements of HR proteins in IRIFs have revealed a highly dynamic interaction of some of the factors (Rad54 and Rad52) with these apparent long-lasting structures (Essers et al. 2002). The more structural protein Rad51 that forms nucleo-protein filaments exhibits much longer residence times in these foci. Real time imaging in living cells of GFPtagged DSB-DDR protein distribution in response to local damage induction allowed determination of the assembly kinetics of the different factors (Bekker-Jensen et al. 2005). One of the most striking findings in these studies is that assembly occurs in two kinetically separable waves, i.e., an immediate loading of, for example, MRN and MDC1, followed by a second wave of loading of, for example, 53BP1 and BRCA1. This secondary, slower wave has been suggested to retain and concentrate the repair factors near the insult.

It is surprising to note that particularly the DNA repair proteins ( $\operatorname{Rad} 51, \operatorname{Rad} 54$, etc.) are only found in the micro-foci, whereas DDR proteins implicated in damage recognition and signaling appear to accumulate in larger structures. Recently, it was shown that $\mathrm{H} 2 \mathrm{~A}$ and $\mathrm{H} 2 \mathrm{AX}$ ubiquitination occurs in response to DSB and that these modified histones as well as the enzymes RNF8, Ubc13, RNF168, and HERC2 accumulate in large foci (Huen et al. 2007; Mailand et al. 2007; Doil et al. 2009; Stewart et al. 2009; Bekker-Jensen et al. 2010). This histone modification appears to play an important role in recruiting the signaling proteins $53 \mathrm{BP} 1$ and BRCA1. It seems that the larger structures are particularly important for transducing and amplifying damage signaling.

Despite intensive research, the exact molecular function of IRIFs remains enigmatic. The most popular model is that IRIFs serve to locally concentrate the enzymes required for DSB. If that is indeed their prime function, it is surprising to note that such huge amounts of activities are required. The high number of proteins and the long-lasting presence of foci argue that the reaction catalyzed by these enzymes is inefficient. In light of this reasoning, the option that foci represent breaks refractory or difficult to break remains open. Recently, a hint toward the possible molecular function of the large chromatin depositions was revealed by directly targeting DDR factors to specific artificial genomic positions in the absence of actual lesions (Soutoglou and Misteli 2008). Immobilizing repair factors to chromatin elicits a damage signaling response without the actual presence of DNA damage. These data suggest that prolonged binding of repair factors is sufficient to trigger, sustain, and amplify the DNA damage signaling. 
Another interesting debate in the field with respect to structure and nuclear distribution of DSBs is on the choreography of DSBs in the nuclear space and the issue of how ends of different breaks find each other. Chromosomal translocations are initiated by DSBs and it has been shown that translocations between different chromosomes occur in a cell-type specific manner (Meaburn et al. 2007), a phenomenon likely driven by the non-random spatial organization of the genome (Roix et al. 2003; Lanctot et al. 2007; Meaburn and Misteli 2007). These observations favor a so-called "contact-first" model, i.e., that chromosome fibers should be in close proximity to allow translocations, as opposed to a "breakage-first" model in which breaks are mobile and roam the nucleus for interactions. Soutoglou et al. developed an elegant procedure to investigate this enigma by specifically generating a single DSB, using a specific endonuclease site located between two repetitive sequences of distinct repressor binding sites, which can be visualized by different fluorescently-tagged repressors (Soutoglou et al. 2007). With this procedure, very limited movement over time of the DSB was observed, thus supporting the "contact-first" model. In contrast, however, Aten et al. found evidence for the "breakage-first" model, using $\alpha$-partical tracks to inflict DSB (Aten et al. 2004), in which they observed limited movement and fusion of foci. These contradictory findings might be derived from the different experimental procedures and cell-cycle phase in which the analyses are performed. In addition, both models may not be mutually exclusive and both processes may play a role in the process of chromosomal translocations.

\section{Organization of Nucleotide Excision Repair}

In the absence of DNA damage, NER factors are generally homogenously distributed throughout the nucleoplasm (Fig. 3A); however, XPC and TFIIH are exceptions to this rule. XPC appears to co-localize with dense or high DNA concentrations (Hoogstraten et al. 2008) and TFIIH is enriched in the nucleolus (Hoogstraten et al. 2002). Unlike DSB repair, NER factors do not exhibit re-localization into microscopically discernible subnuclear structures upon DNA damage induction, making it difficult to unravel the structural organization of NER-dependent damage response. Despite the absence of microscopically discernable repair foci within NER, live cell studies on NER proteins were, however, the first to reveal the highly dynamic character and mobility of chromatin-transacting proteins in mammalian cells (Houtsmuller et al. 1999). GFP-based studies showed that the NER-specific 5 -endonuclease ERCC1/XPF (Houtsmuller et al. 1999), the damaged DNA binding proteins DDB2 (Luijsterburg et al. 2007) and XPC (Hoogstraten et al. 2008), the damage verification factor XPA (Rademakers et al. 2003), the $3^{\prime}$ endonuclease XPG (Zotter et al. 2006), and the multifunctional TFIIH complex (Hoogstraten et al. 2002; Giglia-Mari et al. 2006) each move with their own unique rate through the nucleus. This notion contrasts to an earlier model, based on isolation of NER factors from cell nuclei, in which it was postulated that an assembly or complex of most NER-factors, i.e., the so-called "nucleotide excision repairosome," forms the functional unit within NER (Svejstrup et al. 1995). Further application of cell lines stably expressing these biologically active GFP-tagged NER factors have allowed detailed analysis of the kinetic properties of each of these factors when actively engaged in NER. The development of a procedure to locally inflict NER-specific DNA damage in mammalian cells at the single cell level, using UV-C light irradiation through a microporous filter (Katsumi et al. 2001; Mone et al. 2001) (Figs. 2 and 3B) and later by the development of UV-C laser microirradiation set-up (Dinant et al. 2007) (Fig. 3D), provided detailed insight into how the different NER factors assemble into NER complexes (Mone et al. 2004; Zotter et al. 2006; Luijsterburg et al. 2007; Alekseev et al. 2008; Hoogstraten et al. 2008; Dinant et al. 2009; Nishi et al. 2009) (Fig. 3E). Additional FRAP studies on a series of NER factors, using different doses of UV (correlating with different concentrations of photo-lesions, which are a prime target for NER), variable repair times and in cell 
lines with distinct NER-efficiencies further provided insight into the kinetic framework of NER in living mammalian cells (Politi et al. 2005; Luijsterburg et al. 2010). Most of the NER factors, with the exception of the DNA damage sensor XPC (Hoogstraten et al. 2008; Nishi et al. 2009), freely diffuse through the nuclear space and only assemble into functional repair complexes at the site of the damage. Advanced modeling based on NER kinetic studies favored a model of kinetic-proofreading to achieve high specificity of lesion recognition by proteins with a relatively low discrimination of damaged sites versus non-damaged DNA (Luijsterburg et al. 2010).

\section{NER and Damage Signaling}

In spite of detailed knowledge on the NER mechanism, the connection with UV-induced DNA damage signaling is less well characterized. The ATR kinase and loading of the 9-1-1 complex involving the RAD17 clamp-loader certainly play a role in UV-damage signaling (Niida and Nakanishi 2006). However, the confounding effect of UV-induced replication stress (Zou and Elledge 2003; Falck et al. 2005) makes it difficult to disentangle NER-related signaling from replication stress-induced signaling. Nevertheless, a direct relationship between NER and checkpoint signaling was identified (Giannattasio et al. 2004). In addition, NERdependent ATR activation and H2AX phosphorylation occurred in non S-phase cells (O’Driscoll et al. 2003; Hanasoge and Ljungman 2007), likely caused by ssDNA-containing NER-intermediates (Stiff et al. 2008). NERprocessing and ATR are also required for UVinduced H2A ubiquitination (Bergink et al. 2006). A similar chromatin mark was found in response to DSBs (Huen et al. 2007; Ikura et al. 2007; Mailand et al. 2007; Nicassio et al. 2007). Strikingly, the enzymes involved in DSBinduced $\mathrm{H} 2 \mathrm{~A}$ ubiquitination, such as UBC13 and RNF8, were also responsible for the NERdependent H2A-ubiquitination (Marteijn et al. 2009). This UV-induced chromatin mark further triggers the recruitment of $\mathrm{MDC} 1$, BRCA1, and 53BP1, factors previously known to function in DSB-induced DDR. These findings suggest highly conserved chromatin modification and loading of signaling factors between entirely distinct DDR pathways, DSB repair, and NER. This notion further corroborates the suggestion that large-scale chromatin modifications in response to DNA damage and local concentration of DDR factors play an important function in damage signal maintenance and amplification (Soutoglou and Misteli 2008; Marteijn et al. 2009).

\section{Dynamic Organization in Somatic Cells}

It is important to keep in mind that all described live cell studies in DNA repair have been conducted on cultured cells. Cultured cells are under constant stress (e.g., atmospheric oxygen) and usually in a highly replicative status. Moreover, physiological processes critically depend on the cellular context or micro-environment (cell-cell contacts with neighboring cells, extracellular matrix, etc.). Within larger animals, more than $90 \%$ of the somatic cells are in a non-proliferative status, thus making extrapolations to the actual in vivo situation even more delicate. To acquire an integral view on DDR in different post-mitotic highly differentiated cells, knock-in mouse models expressing endogenously fluorescently tagged crucial proteins have been generated. In the first example of such a mouse model, the yellow variant of GFP was fused to the XPB subunit of the repair/ transcription factor TFIIH, by targeted integration into the endogenous $X p b$ gene locus (Giglia-Mari et al. 2009). Previous studies in cultured cells showed that TFIIH interacts for a few seconds with transcription initiation sites (Hoogstraten et al. 2002). A similar dynamic behavior was observed in highly proliferative cells in mouse tissue, e.g., skin keratinocytes (Giglia-Mari et al. 2009). Surprisingly, transcription-dependent chromatin binding takes on the order of minutes/hours in post-mitotic cells, such as neurons. This suggests that a wellknown and extensively studied cellular pathway, such as transcription, can have a completely different dynamic organization in different cells. The mechanistic reason for this dynamic 
behavioral change remains enigmatic and will be the next challenge to reveal.

In view of these observations, it remains questionable whether current concepts of DDR functioning are applicable to all cell types and tissues. Is a keratinocyte repairing DNA damage differently than a neuron? Do all DDR factors play similar functions in different cells? Are there also development- and differentiationdriven variations in DDR, and if so, how are they regulated? Intriguingly, differential repair kinetics and damage sensitivities have been found in somatic cultured cells and embryonic stem cells (ESC) (de Waard et al. 2008). Part of these differences can be attributed to a more open chromatin structure in ESC, as further reduction of chromatin compaction by reducing the amount of the linker histone $\mathrm{H} 1$ increased the damage response (Murga et al. 2007).

\section{CONCLUSION}

With the availability of protein tagging technology and advanced confocal imaging, spectacular novel insight in the dynamic interplay of DDR factors with damaged DNA has been gained. These studies have revealed a general minimal model of freely diffusing constituents that assemble in a stochastic fashion with damaged DNA to create dynamic assemblies of multiple factors at these sites to finally exert their function (Dinant et al. 2009; Luijsterburg et al. 2010). This view of the dynamic organization of complex pathways in the mammalian cell nucleus has challenged the current textbook models that give the impression of stable structures containing large complexes, in which all constituents are present at all times.

Live cells studies on DDR have revealed that pathways intermingle and share components. Controlling this complex interplay requires perfect coordination in time and space of functions to ensure stability and maintenance of functions. But differently from man-made machines, the dynamic organization of nuclear functions is not the result of a predefined master plan, but, fascinatingly, is the result of a long evolution process selecting for a subtle mix of stochastic diffusion and protein affinities for optimal performance.

Dynamic studies in living cells and, recently, in living animals, allow us to study repair mechanisms in action. Together with the current "omics" approaches (proteomic, genomic and transcription arrays, deep-sequencing, etc.) and the emerging systems biological procedures, these new tools and techniques provide tremendous opportunities to reach a full understanding of DDR, the biological consequences of inefficient DDR in patients and in the general population, in cancer protection, and in agerelated diseases.

\section{REFERENCES}

Adair GM, Rolig RL, Moore-Faver D, Zabelshansky M, Wilson JH, Nairn RS. 2000. Role of ERCC1 in removal of long non-homologous tails during targeted homologous recombination. Embo J 19: 5552-5561.

Akbari M, Krokan HE. 2008. Cytotoxicity and mutagenicity of endogenous DNA base lesions as potential cause of human aging. Mech Age Dev 129: 353-365.

Alekseev S, Luijsterburg MS, Pines A, Geverts B, Mari PO, Giglia-Mari G, Lans H, Houtsmuller AB, Mullenders LH, Hoeijmakers JH, et al. 2008. Cellular concentrations of DDB2 regulate dynamic binding of DDB1 at UV-induced DNA damage. Mol Cell Biol 28: 74027413.

Almeida KH, Sobol RW. 2007. A unified view of base excision repair: lesion-dependent protein complexes regulated by post-translational modification. DNA Repair 6: 695-711.

Alpi AF, Patel KJ. 2009. Monoubiquitylation in the Fanconi anemia DNA damage response pathway. DNA Repair 8: $430-435$.

Altaf M, Auger A, Covic M, Cote J. 2009. Connection between histone $\mathrm{H} 2 \mathrm{~A}$ variants and chromatin remodeling complexes. Biochem Cell Biol 87: 35-50.

Aten JA, Stap J, Krawczyk PM, van Oven CH, Hoebe RA, Essers J, Kanaar R. 2004. Dynamics of DNA doublestrand breaks revealed by clustering of damaged chromosome domains. Science 303: 92-95.

Ayoub N, Jeyasekharan AD, Bernal JA, Venkitaraman AR. 2008. HP1-beta mobilization promotes chromatin changes that initiate the DNA damage response. Nature 453: 682-686.

Ball AR Jr, Yokomori K. 2009. Revisiting the role of heterochromatin protein 1 in DNA repair. J Cell Biol 185: $573-575$.

Barreto G, Schafer A, Marhold J, Stach D, Swaminathan SK, Handa V, Doderlein G, Maltry N, Wu W, Lyko F, et al. 2007. Gadd45a promotes epigenetic gene activation by repair-mediated DNA demethylation. Nature 445: 671-675. 
Bartek J, Bartkova J, Lukas J. 2007. DNA damage signalling guards against activated oncogenes and tumour progression. Oncogene 26: 7773-7779.

Bekker-Jensen S, Lukas C, Kitagawa R, Melander F, Kastan MB, Bartek J, Lukas J. 2006. Spatial organization of the mammalian genome surveillance machinery in response to DNA strand breaks. J Cell Biol 173: 195-206.

Bekker-Jensen S, Lukas C, Melander F, Bartek J, Lukas J. 2005. Dynamic assembly and sustained retention of 53BP1 at the sites of DNA damage are controlled by Mdc1/NFBD1. J Cell Biol 170: 201-211.

Bekker-Jensen S, Rendtlew Danielsen J, Fugger K, Gromova I, Nerstedt A, Lukas C, Bartek J, Lukas J, Mailand N. 2010. HERC2 coordinates ubiquitin-dependent assembly of DNA repair factors on damaged chromosomes. Nat Cell Biol 12: 80-86.

Bergink S, Jaspers NG, Vermeulen W. 2007. Regulation of UV-induced DNA damage response by ubiquitylation. DNA Repair 6: 1231-1242.

Bergink S, Salomons FA, Hoogstraten D, Groothuis TA, de Waard H, Wu J, Yuan L, Citterio E, Houtsmuller AB, Neefjes J, et al. 2006. DNA damage triggers nucleotide excision repair-dependent monoubiquitylation of histone H2A. Genes Dev 20: 1343-1352.

Bernstein C, Bernstein H, Payne CM, Garewal H. 2002. DNA repair/pro-apoptotic dual-role proteins in five major DNA repair pathways: fail-safe protection against carcinogenesis. Mut Res 511: 145-178.

Bohr VA, Okumoto DS, Hanawalt PC. 1986. Survival of UV-irradiated mammalian cells correlates with efficient DNA repair in an essential gene. Proc Natl Acad Sci 83: 3830-3833.

Bohr VA, Smith CA, Okumoto DS, Hanawalt PC. 1985. DNA repair in an active gene: removal of pyrimidine dimers from the DHFR gene of $\mathrm{CHO}$ cells is much more efficient than in the genome overall. Cell 40: 359-369.

Burma S, Chen BP, Chen DJ. 2006. Role of non-homologous end joining (NHEJ) in maintaining genomic integrity. DNA Repair 5: 1042-1048.

Burma S, Chen DJ. 2004. Role of DNA-PK in the cellular response to DNA double-strand breaks. DNA Repair 3: 909-918.

Cahill D, Connor B, Carney JP. 2006. Mechanisms of eukaryotic DNA double strand break repair. Front Biosci 11: $1958-1976$.

Caldecott KW. 2007. Mammalian single-strand break repair: mechanisms and links with chromatin. DNA Repair 6: 443-453.

Callegari AJ, Kelly TJ. 2007. Shedding light on the DNA damage checkpoint. Cell Cycle 6: 660-666.

Celeste A, Petersen S, Romanienko PJ, Fernandez-Capetillo O, Chen HT, Sedelnikova OA, Reina-San-Martin B, Coppola V, Meffre E, Difilippantonio MJ, et al. 2002. Genomic instability in mice lacking histone H2AX. Science 296: 922-927.

Chen CC, Carson JJ, Feser J, Tamburini B, Zabaronick S, Linger J, Tyler JK. 2008. Acetylated lysine 56 on histone H3 drives chromatin assembly after repair and signals for the completion of repair. Cell 134: 231-243.
Chen Y, Sanchez Y. 2004. Chk1 in the DNA damage response: conserved roles from yeasts to mammals. DNA Repair 3: 1025-1032.

Chu G, Chang E. 1988. Xeroderma pigmentosum group E cells lack a nuclear factor that binds to damaged DNA. Science 242: 564-567.

Citterio E, Van Den Boom V, Schnitzler G, Kanaar R, Bonte E, Kingston RE, Hoeijmakers JH, Vermeulen W. 2000. ATP-Dependent Chromatin Remodeling by the Cockayne Syndrome B DNA Repair-Transcription-Coupling Factor. Mol Cell Biol 20: 7643-7653.

Cremer C, Cremer T, Fukuda M, Nakanishi K. 1980. Detection of laser-UV microirradiation-induced DNA photolesions by immunofluorescent staining. Hum Genet 54: $107-110$.

de Jager M, van Noort J, van Gent DC, Dekker C, Kanaar R, Wyman C. 2001. Human Rad50/Mre11 is a flexible complex that can tether DNA ends. Mol Cell 8: 1129-1135.

de Laat WL, Appeldoorn E, Sugasawa K, Weterings E, Jaspers NG, Hoeijmakers JH. 1998. DNA-binding polarity of human replication protein A positions nucleases in nucleotide excision repair. Genes Dev 12: 2598-2609.

de Silva IU, McHugh PJ, Clingen PH, Hartley JA. 2000. Defining the roles of nucleotide excision repair and recombination in the repair of DNA interstrand crosslinks in mammalian cells. Mol Cell Biol 20: 7980-7990.

de Waard H, Sonneveld E, de Wit J, Esveldt-van Lange R, Hoeijmakers JH, Vrieling H, van der Horst GT. 2008. Cell-type-specific consequences of nucleotide excision repair deficiencies: Embryonic stem cells versus fibroblasts. DNA Repair 7: 1659-1669.

Dinant C, de Jager M, Essers J, van Cappellen WA, Kanaar R, Houtsmuller AB, Vermeulen W. 2007. Activation of multiple DNA repair pathways by sub-nuclear damage induction methods. J Cell Sci 120: 2731-2740.

Dinant C, Houtsmuller AB, Vermeulen W. 2008. Chromatin structure and DNA damage repair. Epig \& $C$ 1: 9.

Dinant C, Luijsterburg MS, Hofer T, von Bornstaedt G, Vermeulen W, Houtsmuller AB, van Driel R. 2009. Assembly of multiprotein complexes that control genome function. J Cell Biol 185: 21-26.

Doil C, Mailand N, Bekker-Jensen S, Menard P, Larsen DH, Pepperkok R, Ellenberg J, Panier S, Durocher D, Bartek J, et al. 2009. RNF168 binds and amplifies ubiquitin conjugates on damaged chromosomes to allow accumulation of repair proteins. Cell 136: 435-446.

Downs JA, Lowndes NF, Jackson SP. 2000. A role for Saccharomyces cerevisiae histone H2A in DNA repair. Nature 408: 1001-1004.

Drapkin R, Reardon JT, Ansari A, Huang JC, Zawel L, Ahn K, Sancar A, Reinberg D. 1994. Dual role of TFIIH in DNA excision repair and in transcription by RNA polymerase II. Nature 368: 769-772.

Egly JM. 2001. The 14th Datta Lecture. TFIIH: from transcription to clinic. FEBS Lett 498: 124-128.

El-Khamisy SF, Katyal S, Patel P, Ju L, McKinnon PJ, Caldecott KW. 2009. Synergistic decrease of DNA singlestrand break repair rates in mouse neural cells lacking both Tdp1 and aprataxin. DNA Repair 8: 760-766. 
G. Giglia-Mari, A. Zotter, and W. Vermeulen

Essers J, Houtsmuller AB, van Veelen L, Paulusma C, Nigg AL, Pastink A, Vermeulen W, Hoeijmakers JH, Kanaar R. 2002. Nuclear dynamics of RAD52 group homologous recombination proteins in response to DNA damage. Embo J 21: 2030-2037.

Falck J, Coates J, Jackson SP. 2005. Conserved modes of recruitment of ATM, ATR and DNA-PKcs to sites of DNA damage. Nature 434: 605-611.

Falck J, Petrini JH, Williams BR, Lukas J, Bartek J. 2002. The DNA damage-dependent intra-S phase checkpoint is regulated by parallel pathways. Nat Genet 30: 290-294.

Fousteri M, Mullenders LH. 2008. Transcription-coupled nucleotide excision repair in mammalian cells: molecular mechanisms and biological effects. Cell Res 18: 73-84.

Fousteri M, Vermeulen W, van Zeeland AA, Mullenders LH. 2006. Cockayne syndrome A and B proteins differentially regulate recruitment of chromatin remodeling and repair factors to stalled RNA polymerase II in vivo. Mol Cell 23: 471-482.

Friedberg E, Walker G, Siede W, Wood R, Schultz R, Ellenberg T. 2006. DNA Repair and Mutagenesis. ASM Press, Washington, DC.

Friedberg EC, Lehmann AR, Fuchs RP. 2005. Trading places: how do DNA polymerases switch during translesion DNA synthesis? Mol Cell 18: 499-505.

Giannattasio M, Lazzaro F, Longhese MP, Plevani P, MuziFalconi M. 2004. Physical and functional interactions between nucleotide excision repair and DNA damage checkpoint. Embo J 23: 429-438.

Giglia-Mari G, Miquel C, Theil AF, Mari PO, Hoogstraten D, Ng JM, Dinant C, Hoeijmakers JH, Vermeulen W. 2006. Dynamic interaction of TTDA with TFIIH is stabilized by nucleotide excision repair in living cells. PLoS Biology 4: e156.

Giglia-Mari G, Theil AF, Mari PO, Mourgues S, Nonnekens J, Andrieux L, de Wit J, Miquel C, Wijgers N, Maas A, et al. 2009. Differentiation Driven Changes in the Dynamic Organization of Basal Transcription Initiation. PLoS Biology 7: e1000220.

Gillet LC, Scharer OD. 2006. Molecular mechanisms of mammalian global genome nucleotide excision repair. Chem Rev 106: 253-276.

Goodarzi AA, Noon AT, Deckbar D, Ziv Y, Shiloh Y, Lobrich M, Jeggo PA. 2008. ATM signaling facilitates repair of DNA double-strand breaks associated with heterochromatin. Mol Cell 31: 167-177.

Green CM, Almouzni G. 2002. When repair meets chromatin. First in series on chromatin dynamics. EMBO Rep 3: $28-33$.

Groth A, Rocha W, Verreault A, Almouzni G. 2007. Chromatin challenges during DNA replication and repair. Cell 128: $721-733$.

Gueven N, Becherel OJ, Kijas AW, Chen P, Howe O, Rudolph JH, Gatti R, Date H, Onodera O, Taucher-Scholz G, et al. 2004. Aprataxin, a novel protein that protects against genotoxic stress. Hum Mol Gen 13: 1081-1093.

Hanasoge S, Ljungman M. 2007. H2AX phosphorylation after UV irradiation is triggered by DNA repair intermediates and is mediated by the ATR kinase. Carcinogenesis 28: $2298-2304$.
Hanawalt PC. 1994. Transcription-coupled repair and human disease. Science 266: 1957-1958.

Harper JW, Elledge SJ. 2007. The DNA damage response: ten years after. Mol Cell 28: 739-745.

Hauptner A, Dietzel S, Drexler GA, Reichart P, Krucken R, Cremer T, Friedl AA, Dollinger G. 2004. Microirradiation of cells with energetic heavy ions. Radiat Environ Biophys 42: 237-245.

He H, Lehming N. 2003. Global effects of histone modifications. Brief Funct Genomic Proteomic 2: 234-243.

Hegde ML, Hazra TK, Mitra S. 2008. Early steps in the DNA base excision/single-strand interruption repair pathway in mammalian cells. Cell Res 18: 27-47.

Helleday T, Lo J, van Gent DC, Engelward BP. 2007. DNA double-strand break repair: from mechanistic understanding to cancer treatment. DNA Repair 6: 923-935.

Heo K, Kim H, Choi SH, Choi J, Kim K, Gu J, Lieber MR, Yang AS, An W. 2008. FACT-mediated exchange of histone variant $\mathrm{H} 2 \mathrm{AX}$ regulated by phosphorylation of H2AX and ADP-ribosylation of Spt16. Mol Cell 30: 86-97.

Hoeijmakers JH. 2001. Genome maintenance mechanisms for preventing cancer. Nature 411: 366-374.

Hoeijmakers JH. 2009. DNA damage, aging, and cancer. $N$ Engl J Med 361: 1475-1485.

Hoeijmakers JHJ. 1993. Nucleotide excision repair II: from yeast to mammals. Trends in Gen 9: 211-217.

Hoogstraten D, Bergink S, Ng JM, Verbiest VH, Luijsterburg MS, Geverts B, Raams A, Dinant C, Hoeijmakers JH, Vermeulen W, et al. 2008. Versatile DNA damage detection by the global genome nucleotide excision repair protein XPC. J Cell Sci 121: 2850-2859.

Hoogstraten D, Nigg AL, Heath H, Mullenders LH, van Driel R, Hoeijmakers JH, Vermeulen W, Houtsmuller AB. 2002. Rapid Switching of TFIIH between RNA Polymerase I and II Transcription and DNA Repair In Vivo. Mol Cell 10: 1163-1174.

Houtsmuller AB, Rademakers S, Nigg AL, Hoogstraten D, Hoeijmakers JHJ, Vermeulen W. 1999. Action of DNA repair endonuclease ERCC1/XPF in living cells. Science 284: 958-961.

Houtsmuller AB, Vermeulen W. 2001. Macromolecular dynamics in living cell nuclei revealed by fluorescence redistribution after photobleaching. Histochem Cell Biol 115: $13-21$.

Huen MS, Chen J. 2008. The DNA damage response pathways: at the crossroad of protein modifications. Cell Res 18: $8-16$.

Huen MS, Grant R, Manke I, Minn K, Yu X, Yaffe MB, Chen J. 2007. RNF8 transduces the DNA-damage signal via histone ubiquitylation and checkpoint protein assembly. Cell 131: 901-914.

Ikura T, Tashiro S, Kakino A, Shima H, Jacob N, Amunugama R, Yoder K, Izumi S, Kuraoka I, Tanaka K, et al. 2007. DNA damage-dependent acetylation and ubiquitination of H2AX enhances chromatin dynamics. Mol Cell Biol 27: 7028-7040.

Jakob B, Scholz M, Taucher-Scholz G. 2003. Biological imaging of heavy charged-particle tracks. Radiat Res 159: $676-684$. 
Kastan MB, Bartek J. 2004. Cell-cycle checkpoints and cancer. Nature 432: 316-323.

Katsumi S, Kobayashi N, Imoto K, Nakagawa A, Yamashina Y, Muramatsu T, Shirai T, Miyagawa S, Sugiura S, Hanaoka F, et al. 2001. In situ visualization of ultraviolet-light-induced DNA damage repair in locally irradiated human fibroblasts. J Inves Derma 117: 1156-1161.

Keeney S, Eker APM, Brody T, Vermeulen W, Bootsma D, Hoeijmakers JHJ, Linn S. 1994. correction of the DNA repair defect in xeroderma pigmentosum group E by injection of a DNA damage-binding protein. Proc Nat Acad Sci 91: 4053-4056.

Kim JS, Krasieva TB, LaMorte V, Taylor AM, Yokomori K. 2002. Specific recruitment of human cohesin to laserinduced DNA damage. J Biol Chem 277: 45149-45153.

Lan L, Nakajima S, Oohata Y, Takao M, Okano S, Masutani M, Wilson SH, Yasui A. 2004. In situ analysis of repair processes for oxidative DNA damage in mammalian cells. Proc Natl Acad Sci 101: 13738-13743.

Lanctot C, Cheutin T, Cremer M, Cavalli G, Cremer T. 2007. Dynamic genome architecture in the nuclear space: regulation of gene expression in three dimensions. Nat Rev Genet 8: 104-115.

Lehmann AR. 2006. Translesion synthesis in mammalian cells. Exp Cell Res 312: 2673-2676.

Li B, Carey M, Workman JL. 2007. The role of chromatin during transcription. Cell 128: 707-719.

Li Z, Xiao W, McCormick JJ, Maher VM. 2002. Identification of a protein essential for a major pathway used by human cells to avoid UV- induced DNA damage. Proc Natl Acad Sci 99: 4459-4464.

Limbo O, Chahwan C, Yamada Y, de Bruin RA, Wittenberg C, Russell P. 2007. Ctp1 is a cell-cycle-regulated protein that functions with Mre11 complex to control doublestrand break repair by homologous recombination. Mol Cell 28: 134-146.

Lindahl T. 1993. Instability and decay of the primary structure of DNA. Nature 362: 709-715.

Lippincott-Schwartz J, Snapp E, Kenworthy A. 2001. Studying protein dynamics in living cells. Nature Reviews 2: 444-456.

Lisby M, Barlow JH, Burgess RC, Rothstein R. 2004. Choreography of the DNA damage response: spatiotemporal relationships among checkpoint and repair proteins. Cell 118: 699-713.

Lisby M, Rothstein R. 2009. Choreography of recombination proteins during the DNA damage response. DNA Repair 8: 1068-1076.

Liu M, Schatz DG. 2009. Balancing AID and DNA repair during somatic hypermutation. Trends in $\operatorname{Imm}$ 30: $173-181$.

Loyola A, Almouzni G. 2007. Marking histone H3 variants: how, when and why? Trends in Bioch Sci 32: 425-433.

Luijsterburg MS, Dinant C, Lans H, Stap J, Wiernasz E, Lagerwerf S, Warmerdam DO, Lindh M, Brink MC, Dobrucki JW, et al. 2009. Heterochromatin protein 1 is recruited to various types of DNA damage. J Cell Biol 185: $577-586$.

Luijsterburg MS, Goedhart J, Moser J, Kool H, Geverts B, Houtsmuller AB, Mullenders LH, Vermeulen W, van
Driel R. 2007. Dynamic in vivo interaction of DDB2 E3 ubiquitin ligase with UV-damaged DNA is independent of damage-recognition protein XPC. J Cell Sci 120: 2706-2716.

Luijsterburg MS, von Bornstaedt G, Gourdin AM, Politi AZ, Mone MJ, Warmerdam DO, Goedhart J, Vermeulen W, van Driel R, Hofer T. 2010. Stochastic and reversible assembly of a multiprotein DNA repair complex ensures accurate target site recognition and efficient repair. J Cell Biol 189: 445-463.

Lukas C, Falck J, Bartkova J, Bartek J, Lukas J. 2003. Distinct spatiotemporal dynamics of mammalian checkpoint regulators induced by DNA damage. Nat Cell Biol 5: 255-260.

Mahaney BL, Meek K, Lees-Miller SP. 2009. Repair of ionizing radiation-induced DNA double-strand breaks by non-homologous end-joining. Biochem J 417: 639-650.

Mailand N, Bekker-Jensen S, Faustrup H, Melander F, Bartek J, Lukas C, Lukas J. 2007. RNF8 ubiquitylates histones at DNA double-strand breaks and promotes assembly of repair proteins. Cell 131: 887-900.

Mari P-O, Florea BI, Persengiev SP, Verkaik NS, Bruggenwirth HT, Modesti M, Giglia-Mari G, Bezstarosti K, Demmers JAA, Luider TM, et al. 2006. Dynamic assembly of end-joining complexes requires interaction between Ku70/80 and XRCC4. Proc Natl Acad Sci 103: 18597-18602.

Marteijn JA, Bekker-Jensen S, Mailand N, Lans H, Schwertman P, Gourdin AM, Dantuma NP, Lukas J, Vermeulen W. 2009. Nucleotide Excision Repair-induced H2A ubiquitination is dependent on MDC1 and RNF8 and reveals a universal DNA damage response. J Cell Biol 186: 835-847.

Marti TM, Hefner E, Feeney L, Natale V, Cleaver JE. 2006. H2AX phosphorylation within the G1 phase after UV irradiation depends on nucleotide excision repair and not DNA double-strand breaks. Proc Natl Acad Sci 103: 9891-9896.

Masutani C, Sugasawa K, Yanagisawa J, Sonoyama T, Ui M, Enomoto T, Takio K, Tanaka K, van der Spek PJ, Bootsma D, et al. 1994. Purification and cloning of a nucleotide excision repair complex involving the xeroderma pigmentosum group $\mathrm{C}$ protein and a human homolog of yeast RAD23. EMBO J 13: 1831-1843.

Matsuoka S, Ballif BA, Smogorzewska A, McDonald ER, 3rd Hurov, Luo J, Bakalarski CE, Zhao Z, Solimini N, Lerenthal Y, et al. 2007. ATM and ATR substrate analysis reveals extensive protein networks responsive to DNA damage. Science 316: 1160-1166.

Meaburn KJ, Misteli T. 2007. Cell biology: chromosome territories. Nature 445: 379-781.

Meaburn KJ, Misteli T, Soutoglou E. 2007. Spatial genome organization in the formation of chromosomal translocations. Semin Cancer Biol 17: 80-90.

Meldrum RA, Botchway SW, Wharton CW, Hirst GJ. 2003. Nanoscale spatial induction of ultraviolet photoproducts in cellular DNA by three-photon near-infrared absorption. ЕMBO Rep 4: 1144-1149.

Mello JA, Sillje HH, Roche DM, Kirschner DB, Nigg EA, Almouzni G. 2002. Human Asf1 and CAF-1 interact and synergize in a repair-coupled nucleosome assembly pathway. EMBO Rep 3: 329-334. 
Misteli T, Soutoglou E. 2009. The emerging role of nuclear architecture in DNA repair and genome maintenance. Nature Reviews 10: 243-254.

Mitchell JR, Hoeijmakers JH, Niedernhofer LJ. 2003. Divide and conquer: nucleotide excision repair battles cancer and ageing. Curr Opin Cell Biol 15: 232-240.

Mone MJ, Bernas T, Dinant C, Goedvree FA, Manders EM, Volker M, Houtsmuller AB, Hoeijmakers JH, Vermeulen W, van Driel R. 2004. In vivo dynamics of chromatinassociated complex formation in mammalian nucleotide excision repair. Proc Natl Acad Sci 101: 15933-15937.

Mone MJ, Volker M, Nikaido O, Mullenders LH, van Zeeland AA, Verschure PJ, Manders EM, van Driel R. 2001. Local UV-induced DNA damage in cell nuclei results in local transcription inhibition. EMBO Rep 2: 1013-1017.

Moser J, Kool H, Giakzidis I, Caldecott K, Mullenders LH, Fousteri MI. 2007. Sealing of chromosomal DNA nicks during nucleotide excision repair requires XRCC1 and DNA ligase III alpha in a cell-cycle-specific manner. Mol Cell 27: 311-323.

Murga M, Jaco I, Fan Y, Soria R, Martinez-Pastor B, Cuadrado M, Yang SM, Blasco MA, Skoultchi AI, Fernandez-Capetillo O. 2007. Global chromatin compaction limits the strength of the DNA damage response. J Cell Biol 178: 1101-1108.

Nag R, Smerdon MJ. 2009. Altering the chromatin landscape for nucleotide excision repair. Mut Res 682: 13-20.

Nelms BE, Maser RS, MacKay JF, Lagally MG, Petrini JH. 1998. In situ visualization of DNA double-strand break repair in human fibroblasts. Science 280: 590-592.

Neves-Costa A, Varga-Weisz P. 2006. The roles of chromatin remodelling factors in replication. Results Probl Cell Differ 41: 91-107.

Nicassio F, Corrado N, Vissers JH, Areces LB, Bergink S, Marteijn JA, Geverts B, Houtsmuller AB, Vermeulen W, Di Fiore PP, et al. 2007. Human USP3 is a chromatin modifier required for $\mathrm{S}$ phase progression and genome stability. Curr Biol 17: 1972-1977.

Niedernhofer LJ, Essers J, Weeda G, Beverloo B, de Wit J, Muijtjens M, Odijk H, Hoeijmakers JH, Kanaar R. 2001. The structure-specific endonuclease Erccl-Xpf is required for targeted gene replacement in embryonic stem cells. Embo J 20: 6540-6549.

Niedernhofer LJ, Odijk H, Budzowska M, van Drunen E, Maas A, Theil AF, de Wit J, Jaspers NG, Beverloo HB, Hoeijmakers JH, et al. 2004. The structure-specific endonuclease Erccl-Xpf is required to resolve DNA interstrand cross-link-induced double-strand breaks. $\mathrm{Mol}$ Cell Biol 24: 5776-5787.

Niida H, Nakanishi M. 2006. DNA damage checkpoints in mammals. Mutagenesis 21: 3-9.

Nishi R, Alekseev S, Dinant C, Hoogstraten D, Houtsmuller AB, Hoeijmakers JH, Vermeulen W, Hanaoka F, Sugasawa K. 2009. UV-DDB-dependent regulation of nucleotide excision repair kinetics in living cells. DNA Repair 8: 767-776.

O’Donovan A, Davies AA, Moggs JG, West SC, Wood RD. 1994. XPG endonuclease makes the $3^{\prime}$ incision in human DNA nucleotide excision repair. Nature 371: 432-435.
O’Driscoll M, Ruiz-Perez VL, Woods CG, Jeggo PA, Goodship JA. 2003. A splicing mutation affecting expression of ataxia-telangiectasia and Rad3-related protein (ATR) results in Seckel syndrome. Nat Genet 33: 497-501.

Ogi T, Limsirichaikul S, Overmeer RM, Volker M, Takenaka K, Cloney R, Nakazawa Y, Niimi A, Miki Y, Jaspers NG, et al. 2010. Three DNA polymerases, recruited by different mechanisms, carry out NER repair synthesis in human cells. Mol Cell 37: 714-727.

Panier S, Durocher D. 2009. Regulatory ubiquitylation in response to DNA double-strand breaks. DNA Repair 8: $436-443$.

Phair RD, Misteli T. 2000. High mobility of proteins in the mammalian cell nucleus. Nature 404: 604-609.

Politi A, Mone MJ, Houtsmuller AB, Hoogstraten D, Vermeulen W, Heinrich R, van Driel R. 2005. Mathematical modeling of nucleotide excision repair reveals efficiency of sequential assembly strategies. Mol Cell 19: 679-690.

Polo SE, Roche D, Almouzni G. 2006. New histone incorporation marks sites of UV repair in human cells. Cell 127: 481-493.

Rademakers S, Volker M, Hoogstraten D, Nigg AL, Mone MJ, Van Zeeland AA, Hoeijmakers JH, Houtsmuller AB, Vermeulen W. 2003. Xeroderma pigmentosum group A protein loads as a separate factor onto DNA lesions. Mol Cell Biol 23: 5755-5767.

Reed SH, Gillette TG. 2007. Nucleotide excision repair and the ubiquitin proteasome pathway-do all roads lead to Rome? DNA Repair 6: 149-156.

Rodrigue A, Lafrance M, Gauthier MC, McDonald D, Hendzel M, West SC, Jasin M, Masson JY. 2006. Interplay between human DNA repair proteins at a unique doublestrand break in vivo. $E M B O J$ 25: 222-231.

Rogakou EP, Boon C, Redon C, Bonner WM. 1999. Megabase chromatin domains involved in DNA double-strand breaks in vivo. J Cell Biol 146: 905-916.

Rogakou EP, Pilch DR, Orr AH, Ivanova VS, Bonner WM. 1998. DNA double-stranded breaks induce histone H2AX phosphorylation on serine 139. J Biol Chem 273: 5858-5868.

Roix JJ, McQueen PG, Munson PJ, Parada LA, Misteli T. 2003. Spatial proximity of translocation-prone gene loci in human lymphomas. Nat Genet 34: 287-291.

Saha A, Wittmeyer J, Cairns BR. 2006. Mechanisms for nucleosome movement by ATP-dependent chromatin remodeling complexes. Results Probl Cell Differ 41: 127-148.

Sartori AA, Lukas C, Coates J, Mistrik M, Fu S, Bartek J, Baer R, Lukas J, Jackson SP. 2007. Human CtIP promotes DNA end resection. Nature 450: 509-514.

Schaeffer L, Roy R, Humbert S, Moncollin V, Vermeulen W, Hoeijmakers JHJ, Chambon P, Egly J. 1993. DNA repair helicase: a component of BTF2 (TFIIH) basic transcription factor. Science 260: 58-63.

Scully R, Puget N, Vlasakova K. 2000. DNA polymerase stalling, sister chromatid recombination and the BRCA genes. Oncogene 19: 6176-6183.

Sijbers AM, De Laat WL, Ariza RR, Biggerstaff M, Wei YF, Moggs JG, Carter KC, Shell BK, Evans E, De Jong MC, et al. 1996. Xeroderma pigmentosum group F caused 
by a defect in a structure-specific DNA repair endonuclease. Cell 86: 811-822.

Sinclair DA, Oberdoerffer P. 2009. The ageing epigenome: damaged beyond repair? Age Res Rev 8: 189-198.

Smerdon MJ. 1991. DNA repair and the role of chromatin structure. Curr Opin Cell Biol 3: 422-428.

Smits VA, Warmerdam DO, Martin Y, Freire R. 2010. Mechanisms of ATR-mediated checkpoint signalling. Front Biosci 15: 840-853.

Soutoglou E, Dorn JF, Sengupta K, Jasin M, Nussenzweig A, Ried T, Danuser G, Misteli T. 2007. Positional stability of single double-strand breaks in mammalian cells. Nat Cell Biol 9: 675-682.

Soutoglou E, Misteli T. 2008. Activation of the cellular DNA damage response in the absence of DNA lesions. Science 320: $1507-1510$.

Stewart GS, Panier S, Townsend K, Al-Hakim AK, Kolas NK, Miller ES, Nakada S, Ylanko J, Olivarius S, Mendez M, et al. 2009. The RIDDLE syndrome protein mediates a ubiquitin-dependent signaling cascade at sites of DNA damage. Cell 136: 420-434.

Stiff T, Cerosaletti K, Concannon P, O’Driscoll M, Jeggo PA. 2008. Replication independent ATR signalling leads to G2/M arrest requiring Nbs1, 53BP1 and MDC1. Hum Mol Gen 17: 3247-3253.

Sugasawa K, Akagi J, Nishi R, Iwai S, Hanaoka F. 2009. Twostep recognition of DNA damage for mammalian nucleotide excision repair: Directional binding of the XPC complex and DNA strand scanning. Mol Cell 36: 642-653.

Svejstrup JQ, Wang Z, Feaver WJ, Wu X, Bushnell DA, Donahue TF, Friedberg EC, Kornberg RD. 1995. Different forms of TFIIH for transcription and DNA repair: holo-TFIIH and a nucleotide excision repairosome. Cell 80: $21-28$

Takeda S, Nakamura K, Taniguchi Y, Paull TT. 2007. Ctp1/ CtIP and the MRN complex collaborate in the initial steps of homologous recombination. Mol Cell 28: 351-352.

Tashiro S, Walter J, Shinohara A, Kamada N, Cremer T. 2000. Rad51 accumulation at sites of DNA damage and in postreplicative chromatin. J Cell Biol 150: 283-291.

Tibbetts RS, Cortez D, Brumbaugh KM, Scully R, Livingston D, Elledge SJ, Abraham RT. 2000. Functional interactions between BRCA1 and the checkpoint kinase ATR during genotoxic stress. Genes Dev 14: 2989-3002.

Tsien RY, Miyawaki A. 1998. Seeing the machinery of live cells. Science 280: 1954-1955.

Uematsu N, Weterings E, Yano K, Morotomi-Yano K, Jakob B, Taucher-Scholz G, Mari PO, van Gent DC, Chen BP, Chen DJ. 2007. Autophosphorylation of DNA-PKCS regulates its dynamics at DNA double-strand breaks. J Cell Biol 177: 219-229.

van Attikum H, Fritsch O, Hohn B, Gasser SM. 2004. Recruitment of the INO80 complex by H2A phosphorylation links ATP-dependent chromatin remodeling with DNA double-strand break repair. Cell 119: 777-788.

van Attikum H, Gasser SM. 2009. Crosstalk between histone modifications during the DNA damage response. Trends Cell Biol 19: 207-217. van den Boom V, Citterio E, Hoogstraten D, Zotter A, Egly JM, van Cappellen WA, Hoeijmakers JH, Houtsmuller AB, Vermeulen W. 2004. DNA damage stabilizes interaction of CSB with the transcription elongation machinery. J Cell Biol 166: 27-36.

van Gent DC, van der Burg M. 2007. Non-homologous endjoining, a sticky affair. Oncogene 26: 7731-7740.

Volker M, Moné MJ, Karmakar P, Hoffen A, Schul W, Vermeulen W, Hoeijmakers JHJ, van Driel R, Zeeland AA, Mullenders LHF. 2001. Sequential Assembly of the Nucleotide Excision Repair Factors In Vivo. Mol Cell 8: 213-224.

Warmerdam DO, Freire R, Kanaar R, Smits VA. 2009. Cell cycle-dependent processing of DNA lesions controls localization of Rad 9 to sites of genotoxic stress. Cell Cycle 8: $1765-1774$.

Waters R, Teng Y, Yu Y, Yu S, Reed SH. 2009. Tilting at windmills? The nucleotide excision repair of chromosomal DNA. DNA Repair 8: 146-152.

Weber S. 2005. Light-driven enzymatic catalysis of DNA repair: a review of recent biophysical studies on photolyase. Biochim Biophys Acta 1707: 1-23.

Westerveld A, Hoeijmakers JH, van Duin M, de Wit J, Odijk H, Pastink A, Wood RD, Bootsma D. 1984. Molecular cloning of a human DNA repair gene. Nature 310: 425-429.

Weterings E, van Gent DC. 2004. The mechanism of nonhomologous end-joining: a synopsis of synapsis. DNA Repair 3: 1425-1435.

White J, Stelzer E. 1999. Photobleaching GFP reveals protein dynamics inside live cells. Trends Cell Biol 9: 61-65.

Wyman C, Kanaar R. 2006. DNA double-strand break repair: all's well that ends well. Annu Rev Genet 40: 363-383.

Wyman C, Ristic D, Kanaar R. 2004. Homologous recombination-mediated double-strand break repair. DNA Repair 3: $827-833$.

Yokoi M, Masutani C, Maekawa T, Sugasawa K, Ohkuma Y, Hanaoka F. 2000. The xeroderma pigmentosum group C protein complex XPC-HR23B plays an important role in the recruitment of transcription factor IIH to damaged DNA. J Biol Chem 275: 9870-9875.

Zhou BB, Elledge SJ. 2000. The DNA damage response: putting checkpoints in perspective. Nature 408: 433-439.

Zhu XD, Niedernhofer L, Kuster B, Mann M, Hoeijmakers JH, de Lange T. 2003. ERCC1/XPF removes the 3' overhang from uncapped telomeres and represses formation of telomeric DNA-containing double minute chromosomes. Mol Cell 12: 1489-1498.

Zotter A, Luijsterburg MS, Warmerdam DO, Ibrahim S, Nigg A, van Cappellen WA, Hoeijmakers JH, van Driel R, Vermeulen W, Houtsmuller AB. 2006. Recruitment of the nucleotide excision repair endonuclease XPG to sites of UV-induced dna damage depends on functional TFIIH. Mol Cell Biol 26: 8868-8879.

Zou L, Elledge SJ. 2003. Sensing DNA damage through ATRIP recognition of RPA-ssDNA complexes. Science 300: $1542-1548$. 


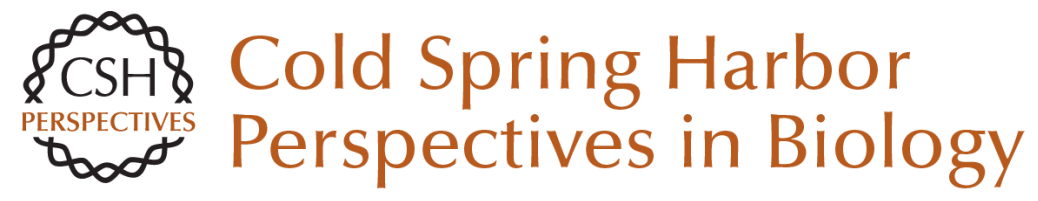

\section{DNA Damage Response}

Giuseppina Giglia-Mari, Angelika Zotter and Wim Vermeulen

Cold Spring Harb Perspect Biol 2011; doi: 10.1101/cshperspect.a000745 originally published online October 27, 2010

\section{Subject Collection The Nucleus}

Nuclear Compartments: An Incomplete Primer to Nuclear Compartments, Bodies, and Genome Organization Relative to Nuclear Architecture Andrew S. Belmont

Uncovering the Principles of Genome Folding by 3D Chromatin Modeling

Asli Yildirim, Lorenzo Boninsegna, Yuxiang Zhan, et al.

3D or Not 3D: Shaping the Genome during Development Juliane Glaser and Stefan Mundlos

The Impact of Space and Time on the Functional Output of the Genome Marcelo Nollmann, Isma Bennabi, Markus Götz, et al.

\section{Chromatin Mechanisms Driving Cancer}

Berkley Gryder, Peter C. Scacheri, Thomas Ried, et al.

\section{Liquid-Liquid Phase Separation in Chromatin} Karsten Rippe

Mechanical Forces in Nuclear Organization Yekaterina A. Miroshnikova and Sara A. Wickström

Imaging Organization of RNA Processing within the Nucleus

Jeetayu Biswas, Weihan Li, Robert H. Singer, et al.
Mechanisms of Chromosome Folding and Nuclear Organization: Their Interplay and Open Questions Leonid Mirny and Job Dekker

Epigenetic Reprogramming in Early Animal Development

Zhenhai Du, Ke Zhang and Wei Xie

Essential Roles for RNA in Shaping Nuclear Organization

Sofia A. Quinodoz and Mitchell Guttman

The Molecular and Nuclear Dynamics of

$\mathrm{X}$-Chromosome Inactivation

François Dossin and Edith Heard

Structure, Maintenance, and Regulation of

Nuclear Pore Complexes: The Gatekeepers of the

Eukaryotic Genome Marcela Raices and Maximiliano A. D'Angelo

The Nuclear Lamina Xianrong Wong, Ashley J. Melendez-Perez and Karen L. Reddy

The Nuclear Pore Complex as a Transcription Regulator Michael Chas Sumner and Jason Brickner

Physical Nature of Chromatin in the Nucleus Kazuhiro Maeshima, Shiori lida and Sachiko Tamura

For additional articles in this collection, see http://cshperspectives.cshlp.org/cgi/collection/

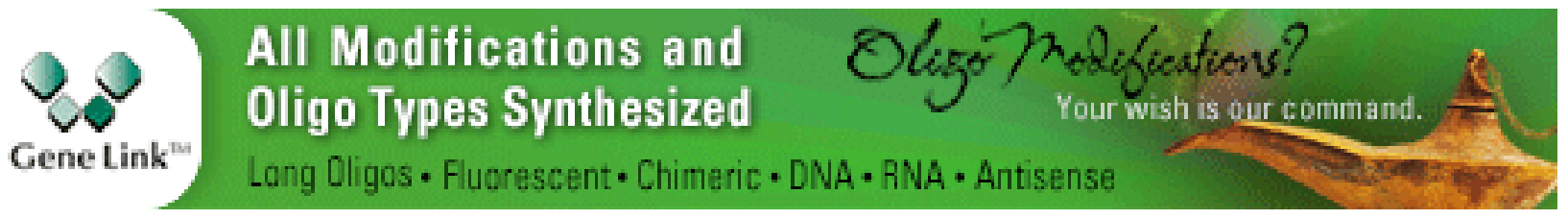


For additional articles in this collection, see http://cshperspectives.cshlp.org/cgi/collection/

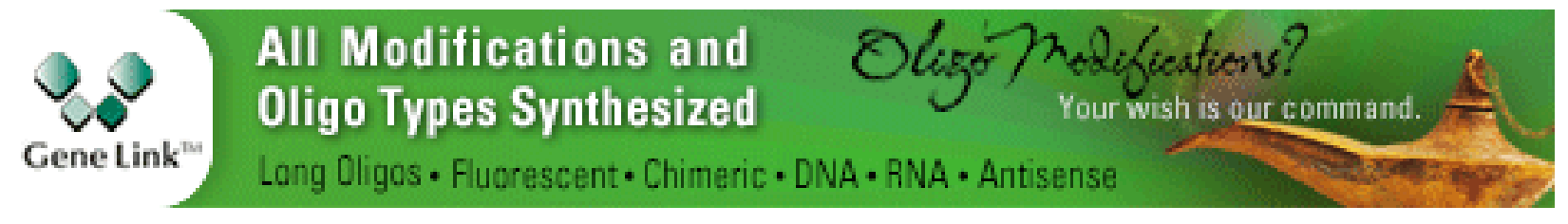

Copyright @ 2011 Cold Spring Harbor Laboratory Press; all rights reserved 